\title{
KAJIAN PERUBAHAN PEMANFAATAN LAHAN DI PESISIR DESA KELAN KELURAHAN TUBAN KECAMATAN KUTA KABUPATEN BADUNG
}

\author{
I Made Agus Sumardita ${ }^{1)}$ \\ 1) Program Studi Magister Arsitektur Fakultas Teknik, Universitas Udayana, Denpasar, \\ Bali \\ Sumardita@gmail.com
}

\begin{abstract}
Significant changes have occurred on the coast of Kelan Beach. Initially, the coast of Kelan Beach was dominated by fishing boat mooring areas and has changed its use to cafes and tourist attractions. This study aims at determining the phenomenon of land use change on the coast of Kelan Beach after the promulgation of Perda Number 26 of 2013 concerning RTRW of Badung Regency which can be grouped into (i) knowing the characteristics of land use in the coastal area of Kelan Village, Tuban Village, Badung Regency after 2013-2017 ( ii) evaluating the suitability of land use 2013-2017 against the $R T R W$ in the coastal area of Kelan Village in 2013-2017 (iii) knowing the land use control strategy in the coastal area of Kelan Village, Tuban Village to comply with the established $R T R W$. This is a qualitative research with descriptive data assessment that is outlined in the form of a report or description. In addition, the nature of the research is field research, namely the data analized obtained through interviews or direct observation. This method was chosen to describe the trends in land use change in an area, the factors that influence the changes, as well as inconsistencies with existing spatial plans. The conclusions of this study are (i) population growth resulting in increased need for spatial use (ii) land use on the coast of Kelan Beach that is not in accordance with RTRW (iii) land use control strategies that need to be reviewed (iv) land use on the coast Kelan, who does not pay attention to the environment, causes chaos and diminishes fishermen's territory.
\end{abstract}

Keywords: coastal, land use, Kelan Beach 


\begin{abstract}
ABSTRAK
Perubahan signifikan telah terjadi pada pesisir Pantai Kelan. Awalnya pesisir Pantai Kelan didominasi oleh area tambatan perahu nelayan telah berubah pemanfaatanya menjadi kafe-kafe dan tempat atraksi wisata. Penelitian ini bertujuan untuk mengetahui fenomena perubahan pemanfaatan lahan di pesisir Pantai Kelan pasca diundangkannya Perda Nomor 26 tahun 2013 tentang RTRW Kabupaten Badung yang dapat dikelompokan menjadi (i) mengetahui karakteristik pemanfaatan lahan pada kawasan pesisir Desa Kelan Kelurahan Tuban Kabupaten Badung pasca tahun 2013-2017 (ii) mengevaluasi kesesuaian penggunaan lahan tahun 2013-2017 terhadap RTRW di wilayah pesisir Desa Kelan tahun 2013-2017 (iii) mengetahui strategi pengendalian pemanfaatan lahan pada kawasan pesisir Desa Kelan Kelurahan Tuban agar sesuai dengan RTRW yang telah ditetapkan. Jenis penelitian yang digunakan dalam penelitian ini adalah jenis penelitian kualitatif dengan pengkajian data deskriptif yang dituangkan dalam bentuk laporan atau uraian selain itu sifat penelitian adalah penelitian lapangan yakni data yang dianalisis diperoleh melalui wawancara atau observasi langsung. Metode ini dipilih untuk menggambarkan kecenderungan perubahan pemanfaatan lahan pada suatu kawasan, faktor-faktor yang mempengaruhi perubahannya, serta ketidaksesuaian dengan rencana tata ruang kawasan yang ada. Adapun kesimpulan dari penelitian ini adalah (i) pertumbuhan penduduk mengakibatkan meningkatnya kebutuhan pemanfaatan ruang (ii) pemanfaatan lahan di pesisir Pantai Kelan yang tidak sesuai dengan RTRW (iii) strategi pengendalian pemanfaatan lahan yang perlu di kaji kembali (iv) pemanfaatan lahan pada pesisir Pantai Kelan yang tidak memperhatikan lingkungan menimbulkan kesemberawutan dan berkurangnya teritori nelayan.
\end{abstract}

Kata kunci: pesisir, pemanfaatan lahan, Pantai Kelan 


\section{PENDAHULUAN}

Sebagai negara kepulauan yang memiliki garis pantai lebih dari $81.000 \mathrm{~km}$, Indonesia membutuhkan pengelola pesisir (coastal manager) yang handal, berkompeten, kreatif dan inovatif. Konsep pengelolaan pesisir secara terpadu tengah dicanangkan oleh masyarakat kelautan. Konsep tersebut merupakan salah satu syarat untuk mencapai pembangunan yang optimal dan berkelanjutan.

Dalam dekade terakhir ini telah terjadi berbagai macam kemunduran fungsi di wilayah pesisir Indonesia. Kemunduran fungsi tersebut sebagian besar disebabkan oleh berkembangnya berbagai jenis kepentingan, akomodasi pariwisata serta pembukaan lahan untuk usaha akuakultur dan pemukiman tanpa melalui studi kelayakan dan studi dampak yang proposional. Pembangunan yang tanpa melalui perencanaan tata ruang/zonasi di kawasan pesisir ini telah menimbulkan kesemerawutan pemanfaatan lahan, seperti hilangnya beberapa akses menuju pantai, menyusutnya kawasan nelayan, dan pelanggaran sempada pantai sehingga semua itu membawa dampak pada berkurangnya ruang-ruang publik maupun kawasan konservasi secara signifikan.
Perubahan-perubahan besar telah terjadi di Bali, baik fisik maupun sosial, ekonomi dan politik sejak Bali ditetapkan sebagai daerah tujuan wisata Indonesia oleh Pemerintah Indonesia pada tahun 1967 (Pitana, 2005). Booming pariwisata Bali terjadi pada tahun 1980an. Pada tahun tersebut Indonesia untuk pertama kali mengkuti World Tourism Market (WTM) menandai dimulainya era promosi pariwisata secara internasional. Pembangunan sarana dan fasilitas pariwisata semakin berkembang. Pembangunan bandara internasional I Gusti Ngurah Rai di Tuban yang bersebelahan dengan pantai Kelan juga menjadi pendorong untuk terjadinya percepatan pembangunan dan perubahan pemanfaatan lahan di kawasan pesisir Desa Kelan.

Sisi utara pantai Kelan sisi utara yang berbatasan dengan Bandara I Gusti Ngurah Rai yang dahulunya merupakan area tambatan kapal nelayan sebagian telah berubah fungsi menjadi cafe-cafe yang menyediakan makanan hasil laut. Penduduk yang dahulunya berprofesi sebagaian sebagai nelayan memiliki pekerjaan sampingan sebagai pedagang di area tersebut. Banyak dari cafe-cafe tersebut melanggar sempadan pantai dan penataan yang kurang terencana. 
Bangunan-bangunan baru yang berdiri sebagai akibat dari berkembangnya pesisir Desa Kelan kenyataanya banyak menyalahi aturan, baik aturan sempadan bangunan maupun sempadan pantai.

Dalam penelitian ini yang menjadi perhatian utama adalah perubahan penggunaan lahan di pesisir Desa Kelan yang diakibatkan oleh peningkatan pembangunan yang bersifat fisik (pembangunan sarana dan prasarana pelayanan penduduk) maupun oleh peningkatan sosial ekonomi penduduk (permukiman, perdagangan, pariwisata dan tempat kegiatan atau usaha lainya). Selain itu memonitoring perubahan penggunaan lahan yang terjadi terhadap Rencana Tata Ruang Wilayah Kabupaten Badung tahun 2013-2033. Pesisir Desa Kelan dimana dalam RTRW direncanakan untuk zona Sempadan Pantai, Zona Kawasan Suci Pantai dan Kawasan Minapolitan namun pada penggunaan lahan tahun 2017 di manfaatkan untuk akomodasi wisata dan perdagangan. Dalam RTRW juga disebutkan bahwa wilayah pesisir Desa Kelan merupakan kawasan rawan intrusi air laut.

\section{KAJIAN PUSTAKA}

\subsection{Kajian Terhadap Penelitian Sejenis}

\subsubsection{Perubahan pemanfaatan lahan pesisir pasca reklamasi di Pulau Serangan \\ Penelitian karya ilmiah ini dilakukan} oleh I Wayan Parwata, I Gede Surya Darmawan, Ni Wayan Nurwarsih (2012). Tujuan dari penelitian ini adalah mengetahui perubahan pemanfaatan lahan pesisir pasca reklamasi Pulau Serangan dan dampak reklamasi bagi kehidupan sosial ekonomi masyarakat di Pulau Serangan. Metode yang dipergunakan dalam penelitian ini adalah metode kualitatif deskriptif karena topik penelitian yang berasal dari fenomena di lapangan yang memiliki nilai lokalitas.

\subsubsection{Identifikasi dampak perubahan fungsi ekosistem pesisir terhadap lingkungan di wilayah pesisir Kecamatan Muaragembong}

Jurnal ini disusun oleh Yulia Astiawati dan Lely Syiddatul Akliyah (2014). Penelitian ini dilatarbelakangi wilayah Pesisir Muaragembong dimanfaatkan sebagai multiuse, mengakibatkan ketidakteraturan dalam pemanfaatan kawasan sehingga menimbulkan perubahan fungsi dari ekosistem pesisir yang mengakibatkan penurunan terhadap kualitas ekosistem dan lingkungan. Hal ini mengakibatkan 
terjadinya kerusakan lingkungan di wilayah pesisir Kecamatan Muaragembong.

\subsubsection{Studi dampak pengembangan pemukiman di wilayah pesisir Surabaya}

Jurnal ini disusun oleh Anna Rosytha (2016). Penelitian ini dilatarbelakangi pesatnya perkembangan Kota Surabaya merupakan faktor penarik bagi penduduk dari luar kota Surabaya untuk urbanisasi dan menetap, pertambahan jumlah penduduk tersebut akan terus menuntut peningkatan ketersediaan jumlah permukiman (real estate), apartement, hotel, pusat-pusatperdagangan (mall) baik di daerah Surabaya Barat maupun di daerah Surabaya Timur, disamping industri dan pergudangan.

\subsection{Landasan Teori}

\subsubsection{Lahan}

Lahan adalah bagian dari bentang alam yang mencangkup pengetian fisik termasuk iklim, topografi/relief, hidrologi bahkan keadaan vegetasi yang secara potensial akan berpengaruh terhadap penggunaan lahan. (FAO, 1976) dalam Tupi, Rio Diharjo (2014).

Dari pengertian diatas dapat disimpulkan bahwa lahan merupakan tanah dengan segala ciri kemampuan maupun sifatnya beserta segala sesuatu yang terdapat diatasnya termasuk didalamnya kegiatan manusia dalam memanfaatkan lahan.

\subsubsection{Ruang}

Ruang merupakan elemen yang sangat penting dalam arsitektur, secara harfiah, ruang (space) berasal dari bahasa latin yaitu spatium yang berarti ruangan atau luas (extent). Jika dilihat dalam bahasa Yunani dapat diartikan sebagai tempat (topos) atau lokasi (choros) yaitu ruang yang memiliki ekspresi kualitas tiga dimensi. Definisi ruang adalah sesuatu yang terukur dan terlihat, dibatasi oleh kejelasan fisik, enclosure yang terlihat sehingga dapat dipahami keberadaannya dengan jelas dan mudah (Ven, 1995).

Prabawasari (1999), menjelaskan definisi ruang adalah suatu wadah yang tidak nyata akan tetapi dapat dirasakan oleh manusia.

\subsubsection{Ruang dalam konteks pemanfaatan lahan \\ Menurut Undang-Undang Nomor 26} Tahun 2007 tentang Penataan Ruang, definisi ruang adalah wadah yang meliputi ruang darat, ruang laut, dan ruang udara, termasuk ruang di dalam bumi sebagai satu kesatuan wilayah, tempat manusia dan makhluk lain hidup, melakukan kegiatan, dan memelihara kelangsungan hidupnya. Sejalan dengan hal tersebut (Friedman and 
Weaver, 1979; Harvey, 1973) mengungkapkan tiga pendekatan yang berkaitan dengan konsepsi ruang (space). Pertama, pendekatan ekologis (ecological approach); kedua, pendekatan ekonomi dan fungsional (functional economical aprroach); ketiga, pendekatan sosial politik (socio-political approach).

\subsubsection{Dinamika pertumbuhan wilayah dan peningkatan kebutuhan lahan}

Dinamika pertumbuhan wilayah perkotaan dan peningkatan kebutuhan lahan adalah suatu rangkaian yang satu sama lain saling mempengaruhi. Menurut (Zahnd, 1999) kehidupan kota sudah lebih disamakan dengan ekologi kota yang melibatkan tiga pokok yang hubungannya sangat erat yakni dinamika secara ekonomi, politis dan budaya kota.

\subsubsection{Perubahan dalam pemanfaatan lahan}

Menurut Chapin, (1996) perubahan guna lahan adalah interaksi yang disebabkan oleh tiga komponen pembentuk guna lahan, yaitu sistem pembangunan, sistem aktivitas dan sistem lingkungan hidup. Didalam sistem aktivitas, konteks perekonomian aktivitas perkotaan dapat dikelompokkan menjadi kegiatan produksi dan konsumsi. Perubahan guna lahan juga terjadi karena kegagalan mempertermukan aspek dan politis dalam suatu manajemen perubahan guna lahan (Chapin, Kaiser, Godschalk 1995).

\subsubsection{Kepentingan dalam pemanfaatan lahan}

Chapin

kemudian mengidentifikasi ada tiga kelompok kepentingan (interest) dalam pemanfaatan lahan secara umum. Pertama, faktor ekonomi yang berorientasikan pada kepentingan pengembangan modal finansial (profit making values). Kedua, faktor pemenuhan kebutuhan dasar dan menjaga keberlangsungan hidup masyarakat umum (public interest values). Ketiga, faktor nilai-nilai sosial bertumbuh kembang di daerah dimana lahan itu berada (socially rooted values). Suartika (2005, 2007, 2010) kemudian menambahkan aspek kepentingan politik (political interest) dalam mempengaruhi pemanfaatan lahan disuatu tempat.

\subsubsection{Bentuk-bentuk kepentingan \\ kompetisi}

Kompetisi sebagai sebuah proses sosial, diartikan sebagai individu atau kelompok-kelompok manusia yang bersaing mencara keuntungan melalui bidang-bidang kehidupan yang pada suatu masa tertentu tanpa menggunakan ancaman atau kekerasan. Bentuk kompetisi kepentingan kemudian dibagi menjadi dua jenis yaitu kompetisi yang bersifat pribadi 
(rivalry) dan kompetisi yang bersifat kelompok.

\subsubsection{Teori kebijakan}

Secara umum istilah kebijakan atau policy digunakan untuk menunjuk seorang aktor (misalnya seorang pejabat, suatu kelompok, maupun suatu lembaga pemerintah) atau sejumlah aktor dalam suatu bidang kegiatan tertentu. Robert Eyestone (1978) mengemukakan bahwa secara luas kebijakan publik dapat didefinisikan sebagai hubungan suatu unit pemerintah dengan lingkungannya. Selanjutnya Thomas R. Dye (1987) mengemukakan bahwa kebijakan publik adalah apapun yang dipilih oleh pemerintah untuk dilakukan dan tidak dilakukan. Richard Rose (2005) menyarankan bahwa kebijakan hendaknya dipahami sebagi arah atau pola kegiatan yang sedikit banyak berhubungan beserta konsekuensi-konsekuensinya bagi mereka yang bersangkutan daripada sebagai suatu keputusan-keputusan tersendiri.

\section{METODE PENELITIAN}

Jenis penelitian yang digunakan dalam penelitian ini adalah jenis penelitian kualitatif dengan dengan pengkajian data deskriptif yang dituangkan dalam bentuk laporan atau uraian selain itu sifat penelitian adalah penelitian lapangan yakni data yang dianalisis didapat dari lapangan yang diperoleh melalui wawancara atau observasi langsung. Data wawancara didapat dari 10 (sepuluh) informan, 5 (lima) dari masyarakat dan 5 (lima) dari unsur pemerintah. Jenis pendekatan penelitian yang digunakan adalah deskriptif.

\section{HASIL DAN PEMBAHASAN}

Tuban adalah kelurahan di kecamatan Kuta, Badung, Provinsi Bali, Desa Kelan merupakan bagian dari Kelurahan Tuban, Kecamatan Kuta, Badung, Bali, Indonesia. Desa Kelan terletak di sebelah selatan Bandara Ngurah Rai Bali, tepatnya di Utara Desa Kedonganan (Gambar 1). Kelan memiliki 1 Desa Adat dan 2 Desa Pakraman yaitu Banjar Kelan Desa dan Banjar Kelan Abian. Masing-masing Banjar memiliki jumlah KK kurang lebih $350 \mathrm{KK}$ dengan mata pencaharian utama nelayan dan bertani. Tapi dengan adanya perubahan era moderisasi sebagian penduduk sebagai masyarakat Kelan bekerja di Kawasan Bandara Internasional Ngurah Rai, Bali.

Aktivitas utama di Desa Kelan tidak lagi pada sektor perikanan melainkan sektor pariwisata dan perdagangan. Fungsi kawasan Pantai Kelan dalam Rencana Tata Ruang Wilayah (RTRW) Kabupaten 
Badung Tahun 2013-2033 diarahkan sebagai kawasan Suci Pantai yaitu dimanfaatkan untuk upacara melasti, Pantai Kelan juga termasuk dalam Kawasan Sempadan Pantai. Selanjutnya disebutkan juga bahwa Pantai Kelan disebutkan sebagai Kawasan Peruntukan Kegiatan Perikanan (Kawasan Minapolitan).

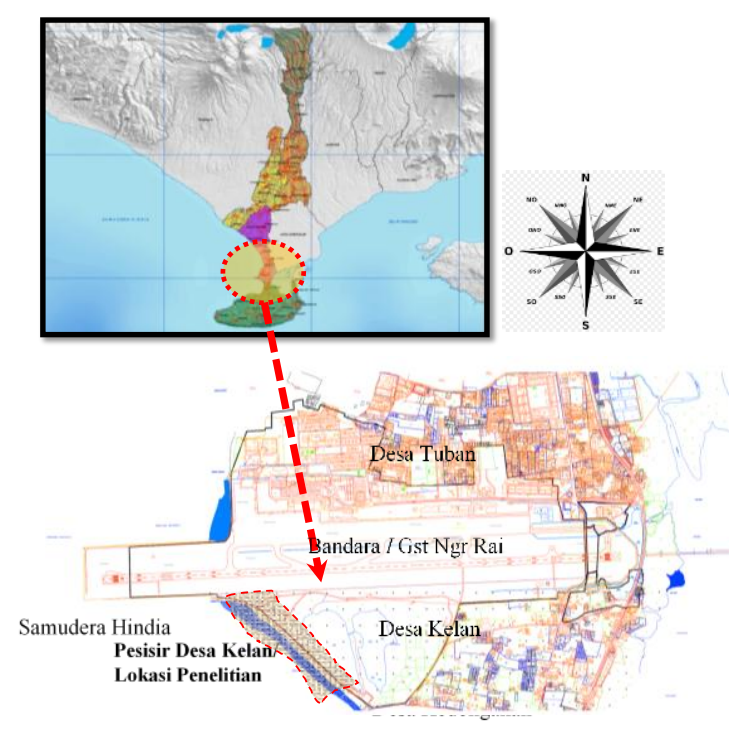

Gambar 1. Lokasi Penelitian

(Sumber: Bidang Tata Ruang DPUPR Kab. Badung, 2017)

\subsection{Karakteristik Pemanfaatan Ruang di Pesisir Desa Kelan}

Perubahan yang paling mendominasi kawasan pesisir Desa Kelan adalah semakin banyaknya terbangun cafe-cafe dan atraksi wisata hingga bersebelahan langsung dengan bandara I Gusti Ngurah Rai. Tumbuhnya bangunan-bangunan tersebut cukup signifikan merubah wajah pesisir Desa Kelan. Dahulu sebagian besar kawasan tersebut merupakan teritori nelayan sedikit demi sedikit telah beralih fungsi (Gambar 2). Bertambahnya kafekafe terutama di bagian utara yang berbatasan dengan bandara I Gusti Ngurah Rai dimulai dari awal tahun 2017 yang secara signifikan mengurangi area tambatan perahu nelayan.

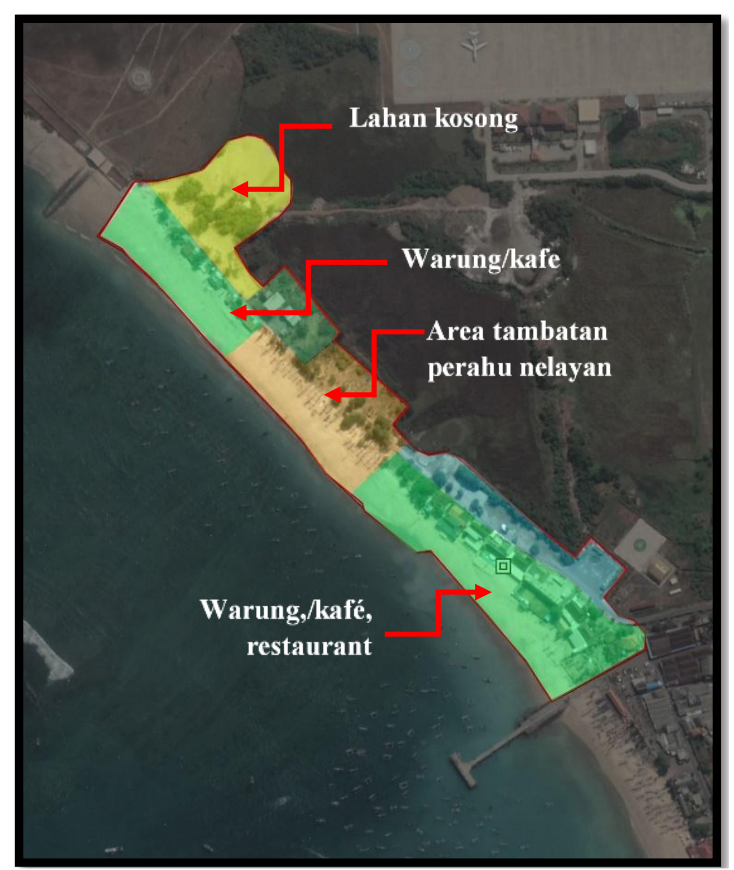

Gambar 2. Pemanfaatan Lahan di Pesisir Pantai Kelan

\subsection{Pelaku Pemanfaatan Lahan Wilayah Pesisir Desa Kelan}

Wilayah pesisir Desa Kelan merupakan kawasan strategis bagi penduduk sekitar dimana sebagian besar masyarakat Desa Kelan menggantungkan hidupnya dari kawasan pesisir terebut. Berbagai pelaku ataupun aktor yang berperan dalam pemanfaatan wilayah pesisir tersebut dapat diidentifikasi seperti Tabel 1. 
Tabel 1. Aktor Yang Berperan Dalam Pemanfaatan Wilayah Pesisir Desa Kelan

\begin{tabular}{|c|c|}
\hline Pelaku & Kepentingan \\
\hline $\begin{array}{l}\text { Nelayan/ } \\
\text { Kelompok } \\
\text { Nelayan }\end{array}$ & $\begin{array}{l}\text { Memiliki kepentingan dalam hal } \\
\text { mata pencaharian dalam bidang } \\
\text { perikanan, sebagai teritori } \\
\text { tambatan perahu. Penyewaan } \\
\text { perahu bagi pengunjung. }\end{array}$ \\
\hline $\begin{array}{l}\text { Pedagang/ } \\
\text { Jasa Kafe- } \\
\text { Kafe }\end{array}$ & $\begin{array}{l}\text { Memiki kepentingan dalam hal } \\
\text { mata pencaharian, tempat } \\
\text { berdagang }\end{array}$ \\
\hline $\begin{array}{l}\text { Pelaku } \\
\text { Wisata }\end{array}$ & $\begin{array}{l}\text { Memiliki kepentingan dalam hal } \\
\text { mata pencaharian, memanfaatkan } \\
\text { wilayah pesisir sebagai jasa } \\
\text { wisata, kepentingan rekreasi dan } \\
\text { sebagainya. }\end{array}$ \\
\hline $\begin{array}{l}\text { Pemerintah } \\
\text { Desa }\end{array}$ & $\begin{array}{l}\text { Memiliki kepentingan dan } \\
\text { tanggung jawab untuk menjaga } \\
\text { keberlangsungan pemanfaatan } \\
\text { wilayah pesisir agar bermanfaat } \\
\text { bagi masyarakat Desa Kelan }\end{array}$ \\
\hline $\begin{array}{l}\text { Pemerintah } \\
\text { Daerah }\end{array}$ & $\begin{array}{l}\text { Memiliki kepentingan dan } \\
\text { tanggung jawab untuk menjaga } \\
\text { keberlangsungan pemanfaatan } \\
\text { wilayah pesisir agar bermanfaat } \\
\text { bagi masyarakat Desa Kelan, } \\
\text { mengatur regulasi, pengendalian } \\
\text { dan pembinaan kepada } \\
\text { masyarakat maupun lingkungan } \\
\text { pesisir Desa Kelan }\end{array}$ \\
\hline
\end{tabular}

\subsection{Kesesuaian Penggunaan Lahan Tahun 2013-2017 Terhadap RTRW di Wilayah Pesisir Desa Kelan}

Dalam mengidentifikasi kesesuaian pemanfaatan lahan pesisir diperlukan data mengenai kondisi terkini pemanfaatan ruang didaerah tersebut, berupa pariwisata, perekoniman, RTH, Perumahan, Pendidikan, dan Sempadan Pantai, lalu kemudian disandingkan dengan data RTRW mengenai kawasan masing-masing. Kesesuaian atapun ketidaksesuaian penggunaan lahan pada pesisir Desa Kelan terhadap RTRW Kabupaten Badung 20132033 dapat dikelompokan atau dikategorikan dalam bentuk pelanggaran pemanfaatan lahan meliputi:

1. Pelanggaran Fungsi (FP)

Pemanfaatan ruang pesisir Desa

Kelan yang diperuntukan sebagai kawasan Sempadan Pantai, Kawasan Konservasi Pantai, Zona Kawasan Suci Pantai dan Kawasan Minapolitan namun dalam penerapanya pada wilayah pesisir Desa Kelan dimanfaatkan sebagai perdagangan.

2. Pelanggaran Peruntukan (PP) Merupakan pelanggaran pemanfaatan ruang yang tidak sesuai dengan peruntukannya sebagaimana ditetapkan dalam rencana tata ruang. Untuk pesisir Desa Kelan peruntukannya untuk kegiatan perikanan/ minapolitan namun dimanfaatkan untuk kegiatan pariwisata dan perdagangan.

3. Pelanggaran tapak kawasan

Merupakan perubahan pemanfaatan ruang dalam satu kawasan yang tidak sesuai dengan pola pemanfaatan yang telah ditetapkan dalam rencana tata ruang.

4. Pelanggaran atas peraturan zonasi (persyaratan teknis bangunan) Yaitu pemanfaatan ruang yang mengabaikan 
persyaratan teknis yang ditetapkan dalam suatu kawasan. Pada pesisir Desa Kelan yang dilanggar adalah persyaratan terhadap sempadan jalan dan pantai.

Bentuk-bentuk penyimpangan yang terjadi dalam pelaksanaan pemanfataan ruang di daerah pesisir Desa Kelan dapat diidentifikasi sebagai berikut:

1. Melanggar batas sempadan yang telah ditentukan.

2. Melanggar ketentuan koefisein lantai bangunan yang telah ditentukan.

3. Melanggar ketentuan koefisien dasar bangunan dan koefisen dasar hijau.

4. Tidak menyediakan fasilitas sosial maupun fasilitas umum sesuai dalam persyaratan ijin pemanfaatan ruang.

\subsection{Strategi Pengendalian Pemanfaatan Tata Ruang pada Kawasan Pesisir Desa Kelan Kelurahan Tuban}

4.4.1 Faktor pendukung dalam pengendalian pemanfaatan tata ruang pada kawasan pesisir Desa Kelan Kelurahan Tuban

1. Potensi pemanfaatan tata ruang pesisir Pantai Kelan merupakan daerah pesisir pantai yang berpotensi untuk pengembangan budidaya perikanan dan ruang terbuka hijau, dari sini pemerintah dapat memberikan insentif terhadap pengembangan potensi fisik tersebut.

2. Potensi pengembangan ekonomi dan pariwisata, seperti yang diketahui bersama sektor ekonomi dan pariwisata merupakan satu kesatuan sektor andalan dalam pengembangan Kawasan pariwisata pesisir, jika dalam suatu kawasan telah berjalan sebuah kegiatan pariwisata maka kegiatan ekonomi akan jalan bersamaan, pengembangan ekonomi dan pariwisata pada kawasan pesisir pantai berpotensi untuk wisata alam, perdagangan dan jasa serta berupa cafe dan restoran dengan wisata alam, hal ini tentunya dapat diberikan insentif karena pemanfaatan ruang yang sesuai dengan RTRW.

\subsubsection{Faktor penghambat dalam pengedalian pemanfaatan tata ruang pada kawasan pesisir Desa Kelan Kelurahan Tuban}

1. Masalah Fisik.

Identifikasi masalah fisik merupakan hal yang penting untuk dibahas dalam pengendalian, 
pemanfaatan ruang, karena bisa terjadi penggunaan lahan yang tidak sesuai dengan peruntukannya sehingga memberikan hasil yang tidak optimal dan merugikan, masalah fisik seperti ini perlu diberikan disinsentif dalam mendukung pemanfaatan ruang yang sesuai dengan rencana tata ruang.

\section{Masalah Tata Ruang}

Tingkat partisipasi dan pendayagunaan rencana tata ruang wilayah masih rendah oleh masyarakat kawasan pesisir pantai dan kurangnya sosialisasi mengenai pengendalian pemanfaatan ruang dari aparat pemerintah untuk masyarakat kawasan pariwisata pesisir pantai.

\subsubsection{Upaya pengendalian perubahan} pemanfaatan tata ruang pada kawasan pesisir Desa Kelan Kelurahan Tuban.

3. Peraturan zonasi

Peraturan zonasi seperti tersebut di atas sebagai pedoman pengendalian pemanfaatan ruang, peraturan zonasi disusun berdasar rencana tata ruang wilayah Kabupaten Badung dalam bentuk rencana rinci tata ruang. Rencana Rinci Tata Ruang meliputi:
a. Rencana Rinci Tata Ruang Kawasan Perkotaan.
b. Rencana Rinci Tata Ruang Kawasan Lindung dan Kawasan Budidaya.
c. Rencana Rinci Tata Ruang Kawasan Strategis Provinsi.

\section{Perizinan}

Perizinan merupakan pedoman pemanfaatan ruang, dimana setiap orang yang akan memanfaatkan ruang wajib memiliki izin Pemanfaatan Ruang, Izin diajukan kepada Bupati melalui Kepala Dinas. Izin Pemanfaatan Ruang terdiri atas:

a. Izin Lokasi yang menyangkut fungsi ruang;

b. Amplop ruang mencakup koefisien dasar ruang hijau, koefisien dasar bangunan, koefisien lantai bangunan, dan garis sempadan bangunan; dan

c. Kualitas ruang merupakan kondisi ruang yang harus dicapai setelah dimanfaatkan (kondisi udara, tanah, air, hidrogeologi, flora dan fauna). 
5. Insentif dan disinsentif

Fungsi dari insentif dan

disinsentif merupakan acuan

pengendalian pemanfaatan ruang wilayah provinsi maupun

kabupaten/kota. Insentif dapat diberikan kepada setiap orang yang melaksanakan

kegiatan

memanfaatkan ruang sejalan dengan rencana tata ruang wilayah kabupaten Badung.

\section{Pengenaan sanksi}

Sanksi dikenakan pada kegiatan pemanfaatan ruang yang tidak sesuai dengan rencana tata ruang wilayah kabupaten dalam bentuk:

a. Pelanggaran ketentuan arahan peraturan zonasi di daerah;

b. Pemanfaatan ruang tanpa izin yang diterbitkan berdasarkan rencana tata ruang wilayah kabupaten;

c. Pelaksanaan pemanfaatan ruang yang tidak sesuai dengan izin yang diterbitkan berdasarkan rencana tata ruang wilayah kabupaten;

d. Pelanggaran ketentuan yang ditetapkan dalam persyaratan izin yang diterbitkan berdasarkan rencana tata ruang wilayah kabupaten;

e. Pemanfaatan ruang yang menghalangi akses terhadap kawasan yang oleh pengaturan perundangudangan dinyatakan sebagai milik umum; dan atau

f. Pemanfaatan ruang dengan izin yang diperoleh dengan prosedur yang tidak benar.

7. Penyusunan, revisi dan evaluasi dokumen rencana tata ruang wilayah sesuai ketentuan

Salah satunya dengan mengakomodasi perubahan kawasan pesisir Pantai Kelan menjadi zona campuran dalam RDTR, dengan mempertimbangkan keberlanjutan ekonomi masyarakat di Desa Kelan yang lebih banyak menggantungkan hidup dari sektor pariwisata dengan tetap memperhatikan faktor lingkungan alam dengan batasan dan syarat-syarat yang diatur dalam Peraturan Zonasi.

8. Pemantauan

Bentuk pemantauan adalah usaha atau perbuatan mengamati, mengawasi dan memeriksa dengan cermat perubahan kualitas tata ruang 
dan lingkungan yang tidak sesuai dengan rencana tata ruang

9. Pelaporan

Pelaporan adalah kegiatan memberikan informasi secara objektif mengenai pemanfaatan ruang baik yang sesuai maupun yang tidak sesuai dengan rencana tata ruang. Pelaporan dikoordinasikan oleh Badan Koordinasi Penataan Ruang Daerah (BKPRD) setiap tahunnya yang berisikan hasil-hasil pelaksanaan tata ruang.

\section{Sosialisasi}

Kegiatan sosialisasi pemanfaatan tata ruang bertujuan untuk meminimalisir pelanggaran pemanfaatan ruang sehingga akan tercipta pemanfaatan ruang yang sesuai dengan peraturan yang ada.

\section{SIMPULAN DAN SARAN}

\subsection{Simpulan}

Dari hasil kajian literatur, hasil dan pembahasan dapat diambil beberapa kesimpulan antara lain:

1. Perkembangan jumlah penduduk di Kelurahan Tuban dengan berbagai aktivitasnya di wilayah pesisir Pantai Kelan dan sekitarnya membawa konsekuensi meningkatnya kebutuhan ruang serta fungsi ruang di wilayah pesisir Pantai Kelan

2. Pemanfaatan lahan di pesisir Pantai Kelan dan sekitarnya yang tidak sesuai dengan rencana tata ruang berimplikasi terhadap kemunduran fungsi di wilayah pesisir Pantai Kelan secara signifikan seperti ketidakseuaian pemanfaatan tata ruang, menyusutnya wilayah nelayan, pelanggaran terhadap sempadan pantai dan jalan.

3. Strategi pengendalian pemanfaatan tata ruang pada kawasan pesisir Pantai Kelan seharusnya harus melihat kepada faktor ekonomi, sosial dan lingkungan. Meningkatnya kebutuhan ekonomi, lemahnya penegakan hukum dalam pemanfaatan wilayah pesisir di pesisir Pantai Kelan merupakan masalah klasik yang timbul dari tidak terpadunya pengelolaan wilayah pesisir Pantai Kelan khususnya.

4. Wilayah pesisir mempunyai arti strategis baik secara ekonomi, sosial dan lingkungan. Pemanfaatan sumberdaya alam 
yang terdapat di wilayah pesisir yang tidak memperhatikan kesimbangan lingkungan, akan memberikan ekesternalitas negatif terhadap lingkungan dan kondisi sosial masyarakat. Eksternalitas negatif dari pemanfaatan sumber daya alam di wilayah pesisisr yang tidak memperhatikan kaidah kesimbangan lingkungan di wilayah pesisir Pantai Kelan adalah terjadinya kesembrawautan tata ruang dan berkurangnya wilayah nelayan yang mengakibatkan kerugian terhadap masyarakat dan lingkungan.

\subsection{Saran}

1. Perkembangan jumlah penduduk di Kelurahan Tuban yang cukup signifikan dimana lonjakan terjadi sejak tahun 2013 dimana saat itu jumlah penduduk Tuban sebesar 13.979 jiwa dan pada tahun 2016 menjadi 20.999 jiwa. Kepadatan yang sebelumnya di angka 5.216 per $\mathrm{km} 2$ menjadi 7.862 jiwa per $\mathrm{km} 2$. Hal ini perlu dikendalikan oleh stakeholder terkait terutama pengendalian kepada penduduk pendatang sehingga kebutuhan terhadap ruang juga bisa dikendalikan.

2. Adanya ketidaksesuaian pemanfaatan lahan di pesisir Pantai Kelan dan sekitarnya yang tidak sesuai dengan rencana tata ruang dapat diminimalisir ataupun diatasi oleh penegakan aturan yang dimiliki, sosialisasi oleh pemerintah daerah kepada pemerintah desa dan elemen masyarakat setempat.

3. Strategi pengendalian pemanfaatan tata ruang pada kawasan Pantai Kelan seharusnya dilakukan secara terencana dan terpadu, harus melihat kepada faktor ekonomi, sosial dan lingkungan.

a. Dari sektor ekonomi:

i. Pada sektor ekonomi pemerintah wajib menjamin dan menjaga keberlangsungan profesi nelayan dan kegiatan pendukung perikanan dan memberi porsi yang adil terhadap sektor pariwisata di pesisir Desa Kelan sehingga tidak 


$$
\begin{aligned}
& \text { banyak nelayan yang } \\
& \text { meninggalkan profesi } \\
& \text { sebelumnya. } \\
& \text { ii. Memberikan insentif } \\
& \text { dapat berupa bantuan } \\
& \text { modal, pengurangan } \\
& \text { pajak terhadap lahan } \\
& \text { yang berupa ruang } \\
& \text { tebuka serta memberikan } \\
& \text { pelatihan keterampilan } \\
& \text { kepada masyarakat. }
\end{aligned}
$$

b. Dari sektor sosial:

i. Kewajiban menjaga adat dan budaya harus dipahami oleh semua stakeholder tarkait. Kawasan pesisir pantai Kelan yang merupakan kawasan suci pantai sudah seharusnya dijaga dan dipertahankan keberadaanya dengan sungguh-sungguh.

Keberadaan

pemerintahan desa sangat berperan penting demi menjaga kelestariannya.

ii. Keberagaman penduduk di kelurahan Tuban yang majemuk sudah seharusnya menjadi potensi yang baik, namun jika tidak dikelola dan dikendalikan dengan baik akan menimbulkan potensi kearah yang negatif seperti kesembrawutan bangunan permukiman, pertumbuhan penduduk yang tinggi dan ancaman keamanan dan ketertiban.

c. Dari sektor lingkungan:

i. Pesisir Pantai Kelan yang merupakan kawasan sempadan pantai, zona kawasan suci pantai dan kawasan minapolitan mesti dijaga keberlangsungannya. Penerapan aturan yang ketat terutama aturan zonasi wilayah, sempadan pantai, sempadan bangunan, KDB, KLB adalah untuk menjaga lingkungan.

ii. Petugas hendaknya menindak tegas terhadapat pelanggar kebersihan lingkungan sebab di wilayah pesisir pantai Desa Kelan 


$$
\begin{aligned}
& \text { banyak penduduk } \\
& \text { maupun pengunjung } \\
& \text { yang tidak } \\
& \text { memperhatikan masalah } \\
& \text { lingkungan dengan } \\
& \text { membuang sampah tidak } \\
& \text { pada tempatnya, } \\
& \text { menebang beberapa } \\
& \text { pohon peneduh, } \\
& \text { pembuangan terdapat } \\
& \text { limbah sisa-sisa } \\
& \text { penangkapan ikan dan } \\
& \text { sebagainya. }
\end{aligned}
$$

4. Meningkatnya kebutuhan ekonomi, lemahnya penegakan hukum dalam pemanfaatan wilayah pesisir di pesisir Pantai Kelan merupakan masalah klasik yang timbul dari tidak terpadunya pengelolaan wilayah pesisir Pantai Kelan khususnya.

5. Perlu adanya konsensus antar kepentingan nilai sosial, mekanisme pasar dan nilai ekologis menjadi indikator manajemen pemanfaatan lahan yang berkelanjutan (suistainable).

\section{DAFTAR PUSTAKA}

Astiawati, Y., \& Akliyah, L. S. (2014). Identifikasi Dampak Perubahan Fungsi Ekosistem Pesisir Terhadap Lingkungan di Wilayah Pesisir Kecamatan Muaragembong. Bandung. Program Studi Perencanaan Wilayah dan Kota Fakultas Teknik Universitas Islam.

Chapin, F. S. (1957). Urban Land Use Planning. New York, NY: Harper \& Brothers

Chapin, F. S., Kaiser, E. J., \& Godschalk, D. R. (1995). Urban Land Use Planning, 4th edition. Illinois. University of Illinois

Dye, T. R. (1987). Understanding Public Policy. United States.

Friedman, J., \& Weaver, C. (1979), Territory and Function: The Evolution of Regional Planning, London Arnold

Northam, R. M. (1979). Urban Geography, Wiley.

Parwata, I W., Darmawan I G. S., \& Nurwarsih, N. W. (2012). Perubahan Pemanfaatan Lahan Pesisir Pasca Reklamasi di Pulau Serangan, Denpasar: Program Studi Teknik Arsitektur Fakultas Teknik UniversitasWarmadewa.

Pitana, I G. (2005). Sosiologi Parwisata. Yogyakarta, Andi offset.

Prabawasari, V. W. \& Suparman, A., (1999). Tata Ruang Luar 01. Jakarta: Penerbit Gunadarma.

Robert, E. (1978). Social Issues. New 
York

Rose, R. (2005). Learning from Comparative Public Policy a Practical Guide. Routledge.

Rosytha, A. (2016). Studi Dampak Pengembangan Pemukiman di Wilayah Pesisir Surabaya. Surabaya. Program Studi Teknik Sipil Universitas Muhammadiyah.

Suartika, G. A. M. (2005), Vanishing Paradise: Planning and Conflict in Bali. Australia. University of New South Wales.

Suartika, G. A. M. (2007), Territoriality and the market system - adat land $v$ s. state regulations on land matters in Bali, Habitat International. Elsevier, USA.

Suartika, G. A. M. (2007), Morphing Bali: The State, Planning and Culture. Germany. Lambert Academic Publishing.

Ven, C. V. D. (1995). Ruang Dalam Arsitektur. Jakarta: Gramedia Pustaka Utama. 